\title{
Current Turnaround Leadership Challenges and Emerging Best Practices in Global Education and Social Development: A Critical Appraisal
}

\author{
Joseph G. Claudet \\ Department of Educational Psychology and Leadership, Texas Tech University, Lubbock TX, United States \\ Email: joe.claudet@ttu.edu
}

\begin{abstract}
This article presents an overview and critical appraisal of current turnaround leadership challenges confronting education leaders today in the design, development, and provision of quality education and social development opportunities for the world's children and youth. Three specific turnaround leadership challenge areas in global education and social development are identified for review. Within each of these three challenge areas, some emerging best practices involving current regional and global collaboration initiatives that demonstrate considerable promise for advancing education and social development opportunities for the world's children and youth are highlighted. The article includes a literature-informed discussion of important dimensions of each of the three identified global education and social development challenge areas along with an appraisal of some creative educational program design ideas for expanding young people's access to high-quality education and career advancement opportunities. Finally, a number of practical education leadership action strategies are offered that educators - working in a variety of education organizations in diverse countries and regions of the world - can consider employing as intentional means to expand and deepen their ongoing educational mentoring and developmental support of children and youth in ways that help young people maximize their twenty-first-century job/career prospects and life-long learning opportunities.
\end{abstract}

Keywords: Global education and social development, educational design initiatives, globally connected learning

\section{Introduction}

As we near the end of the second decade of the twenty-first century, the provision of high-quality, equitable education opportunities as one of several "basic needs" (i.e., food, shelter, clothing, health, and education) to the world's children and youth continues to be a major challenge for education and social development leaders (Moyn, 2018; Rizvi \& Lingard, 2010; World Bank Report, 2015; Zhao, 2012). Continuing population growth in many of the world's nations, along with increasing migrations and relocations of peoples across various geographic areas around the world, have further exacerbated these educational challenges. For example, in the United States continuing influxes of immigrantsparticularly Latina/o population sub-groups from Mexico, Cuba, and Central and South America, but also immigrants from Asia and Europe - have continued to present new challenges to education leaders in providing meaningful learning opportunities to the increasingly diverse populations of students in US elementary and secondary schools. This growing diversification of the national student population base in the United States is a trend that is currently being reflected globally in many other countries as well (McCowan \& Unterhalter, 2015). Unfortunately, in many instances this growing population diversity trend only serves to compound and complicate further the broad problem of educational inequality existing in many geographical regions of the world. This educational inequality is particularly disturbing as these "unequal" educational conditions are overlaid with the politics of change (i.e., the politics associated with "unequal schools and unequal chances") - a phenomenon that manifests itself in differential access to educational and social opportunities for multiple sub-populations and segments of society (Reimers, 2000). This politics of change aspect of schooling involves recognition of the fact that schools are socio-political organizations (Blasé, 1998; Sarason, 1990). In view of this important sociopolitical dimension of schooling, a fundamental aspect of the mission of schools necessarily involves the 
direct connection that can and should exist between how school leaders engage in educational change and, through doing so, seek to leverage their change efforts as a means to alter the social distribution of opportunities to support societal change and learning advancement for all. These change efforts can yield particularly promising new learning and social support opportunities for children and youth when conducted proactively by educational change leaders committed to nurturing creative school program designs and innovative multi-entity collaborative partnerships with a variety of governmental agencies, social service provides, and business and corporate sponsors.

In this article I focus my attention on some current improvement need areas in twenty-first-century schooling that can be particularly challenging to education leaders around the world interested in working collaboratively with societal partners to create positive and equitable learning and social development opportunities for children and youth. In the sections below I begin by providing an overview description of several of these school leadership challenge areas. Following this overview, I then proceed to frame and discuss the global educational and social development needs of twenty-firstcentury children and youth in the context of three critical school turnaround leadership challenge areas of special importance to today's school change leaders. As an integral part of my discussion of each of these three critical turnaround leadership challenge areas, I highlight multiple education and social program initiatives presently operating in various countries and regions of the world - all especially noteworthy because of their creative program designs and innovative partnering strategies - that are accumulating positive track records in addressing effectively the twenty-first-century schooling and social development needs of the world's children and youth.

\section{Turnaround Leadership Challenge Areas in Twenty-First-Century Schooling}

As the second decade of the twenty-first century continues to unfold and the challenges of providing high-quality educational opportunities to children and youth become more complex, the kind of "educational change efforts" required of school leaders has become centered in many regions of society on the need to address critical turnaround leadership challenges in school communities as well as in broader societal processes that can impact effective schooling of children and youth. The term turnaround leadership - used widely within the education and school improvement literature on "school turnarounds" and "school turnaround leadership" that has emerged in recent years (see, for example: Leithwood, et al., 2010; Pappano, 2010) - is applied here to refer broadly to the array of critical education system design, delivery, and improvement challenges being confronted by education leaders in many countries throughout the world today who are striving to effectively serve the learning and social development support needs of economically disadvantaged and marginalized children and youth. These kinds of turnaround leadership challenges often involve multiple, interrelated instructional, economic, and social service problem areas in twenty-first-century school leadership practice and can include, but are not limited to, challenges associated with: 1) serving the learning and family support needs of marginalized students - that is, children and youth from low-income families, non-native languagespeaking students, migrant students, etc.; 2) nurturing and sustaining comprehensive professional learning communities (PLCs) to ensure continuous professional learning and development of school and district teaching staff; 3) developing and implementing multicultural curricula and multicultural learning assessments to address the learning needs of diverse students; 4) designing effective community engagement programs to increase business community member involvement with and funding support of school learning improvement initiatives; 5) creating technology-integrated instructional programs that utilize current mobile digital technologies and social media as twenty-first-century tools for learning; 6) leveraging the availability of the internet and mobile computer technologies/social media to establish and sustain e-Learning Networks in schools and school districts as a means to provide "open digital learning cultures" for students, parents, teachers, school administrators, and school community members; and 7) designing and implementing innovative entrepreneurship education programs that provide young people with relevant applied content, communication, and decision making skills to equip them to be able to compete successfully for twenty-first-century jobs.

To respond to these interrelated problem areas, education leaders today are called upon to renew their commitment to identifying creative program interventions and strategies for addressing the teaching, 
learning, and social development needs of the world's population of children and youth. In the sections below, I frame and discuss these educational and social development needs in the context of three current "school turnaround leadership challenge" areas: 1) serving the needs of economically disadvantaged and marginalized student populations; 2) promoting STEM inquiry and instructional technology integration; and 3) fostering entrepreneurship education. I have selected these specific "school turnaround leadership challenge" areas for review and discussion because these three areas are widely recognized in the recent literature on education and social development as twenty-first-century challenge areas of critical importance for education leaders to address (see, for example: Brown-Martin, 2014; Darling-Hammond, 2010; Hannon, 2013; Leadbeater, 2012; Minniti et al., 2011; Szirmai et al., 2011; World Bank Report, 2015, 2018; Zhao, 2012). As an integral part of my framing of these three current school turnaround leadership challenges, I discuss each of these challenge areas in the context of global education practices today and provide selected examples of innovative programs and emerging best practices from around the world that are presently being implemented to address the learning and social development needs of twenty-first-century children and youth.

\subsection{School Turnaround Leadership Challenges in Serving the Needs of Economically Disadvantaged and Marginalized Student Populations}

Addressing the twenty-first-century education and social development needs of the populations of children and youth around the globe growing up in conditions of poverty continues to be a serious challenge. With substantial population increases occurring in developing regions of the world, including Sub-Saharan Africa and many fragile countries, the world by 2050 will be overwhelmingly comprised of peoples born in economically developing regions, many of them living in conditions of poverty (World Bank Report, 2013, 2015, 2018). Additionally, multiple demographic, spatial, geographic, economic, and knowledge transition factors are further complicating the educational program delivery and social development challenges confronting education and social service organizations in many nations. In particular, increases in migration patterns both within and between countries are resulting in growing urbanization trends and burgeoning population density in large cities and metropolitan areas in countries in Europe, South America, the Middle East, and the Pacific Rim. These expanding migration and urbanization trends, coupled with the multiple specters of global climate change, natural disasters, political instability, and economic recessions, in turn, tend to create new forms of economic and social inequality that can affect access to education, social services, and job and business opportunities. All of these factors, in combination, impact most directly economically disadvantaged families and exacerbate the leadership challenges involved in serving effectively the learning and social development needs of the world's disadvantaged and marginalized populations of children and youth.

Of course, the impact of economic influences looms large as a predictor of success among disadvantaged and marginalized populations of youth who aspire to high-quality educational preparation - both in STEM (science, technology, engineering, and math) and other related professional fields (such as medicine, nursing, and education) - in colleges and universities of higher learning in the United States and in other countries around the world. Indeed, a substantial body of research has emerged in the past two decades underscoring the critical role that financial factors play in determining the educational success of racial and ethnic minority college and university students in STEM and other fields (e.g., Adelman, 2006; Arbona \& Novy, 1990; Chang et al., 2014; Choy, 1999, 2004; Cofer, 2000; Cofer \& Somers, 2000; Cole \& Espinoza, 2008; College Board, 2010; DesJardins et al., 2002; Dowd \& Coury, 2006; Gandara, 2006; Gandara and Contreras, 2009; Heller, 2003; Hess, 2017; Hrabowski \& Maton, 2009; Moore, 2006; Museus, 2010; Strayhorn, 2010; Walpole, 2007). Because the costs of attending colleges and universities around the world are continuing to rise faster than average family incomes, an increasingly large number of today's students - especially students from racial and ethnic minority groups - are continuing to experience significant difficulties in paying for higher education (Hess, 2017).

These educational and social service challenges, however, are not insurmountable. Teams of educators and social entrepreneurs, working in a variety of education and social development organizations around the world, are tackling head-on these challenges through designing innovative programs to meet the learning and social support needs of disadvantaged and marginalized children and youth. Many of these programs have achieved remarkable success in providing new learning opportunities to underserved 
populations of young people around the world and are emerging as noteworthy "case exemplars" of the transformative power of innovative thinking and collaborative team action. In the section below, I highlight and discuss some of these exemplar programs.

\section{Emerging Best Practices: Creating Opportunities for Regional and Global Collaboration in Supporting the Learning and Social Development Needs of Disadvantaged and Marginalized Youth}

There are a number of notable network organizations presently in operation that focus directly on serving the learning and social development needs of disadvantaged and marginalized youth. These organizations share a common vision of providing twenty-first-century education, social services support, and job-related learning opportunities to youth living in low-income communities. For example, the Cristo Rey Network (http://www.cristoreynetwork.org/), the largest high school network of its kind in the United States, focuses on addressing the needs of economically disadvantaged secondary school-age youth. The Cristo Rey Network currently operates schools located in 19 states and the District of Columbia serving a total of 9,800 students. The Cristo Rey Network's distinctive mission is to serve the comprehensive learning and social development needs of low-income, inner city youth-preparing these economically disadvantaged students for success in college and in their adult careers. The Cristo Rey Network design blends high academic expectations with an innovative "Corporate Work Study Program" that provides low-income students with opportunities to gain real-world work experiences in a work-study program with Cristo Rey corporate partners. As a means to gain real-world job experiences and to partly fund their own education, students in the Cristo Rey "work-study program" work five full days each month in work-study placements in law firms, banks, hospitals, universities, and at the offices of other professional corporate partners. In this way, the Cristo Rey curriculum uniquely blends the jobrelated learning students obtain in their work-study program with comprehensive classroom and extracurricular learning experiences to provide a fully integrated learning and social development experience for these economically disadvantaged youth. The Cristo Rey Network presently operates a network of 30 high schools across the United States and maintains partnering relationships with 2,000 corporate partners and 46 university partners.

In addition to the Cristo Rey Network in the United States, other regional educational and social development programs focused on addressing the needs of economically disadvantaged youth exist in North America. For example, Pathways to Education (http://www.pathwaystoeducation.ca) is an innovative, community-based partnership program that provides academic tutoring, social skills development, and financial support to economically disadvantaged youth in low-income communities across Canada. In existence since 2001, the Pathways to Education organization has developed community-based partnerships throughout Canada with programs in Ontario, Quebec, Nova Scotia, Manitoba, and British Columbia. The Pathways to Education organization operates through collaborative partnerships with governments, social welfare agencies, and hundreds of community volunteers. Within this governmental and community partnership design, Pathways to Education partners focus intently on breaking the cycle of poverty and enabling strategic, long-term social change. The Pathways to Education program's innovative, community-based learning model provides economically disadvantaged youth from low-income communities with the academic and social skills mentoring support and financial assistance needed to stay in secondary school, graduate on time, and be academically prepared for college. Pathways program volunteers - student/parent support personnel who take on roles of part-time counselors, advocates, confidantes, social workers, and mediators - work alongside the public school system, providing low-income students with after-school tutoring in core academic subject areas and involving these students in group mentoring activities to help students with social skills development, problem solving, and career planning. In addition, the Pathways to Education program offers low-income students scholarship support and other financial incentives to further support these students in overcoming barriers to completing their education (Pathways to Education, 2015). This combination of after-school tutoring, social skills mentoring, and financial support enables the Pathways to Education program to provide low-income students and their families with academic and social services support that can ensure that these disadvantaged students complete high school and be prepared for college.

In viewing education in the broader context of social development and support for children and youth, a number of organizations in the world today with a global mission and scale are working to provide 
social services and educational opportunities to disadvantaged and marginalized children and youth. At the forefront of these is the global humanitarian organization Save the Children (https://www.savethechildren.net/). Save the Children is the world's leading independent organization focused on serving the social services, education and social development, and advocacy needs of the world's children. The Save the Children organization is comprised of Save the Children International (with central organization offices in London, United Kingdom) and 30 member organizations working to deliver change to children in countries throughout the world. These Save the Children member organizations and their respective Save the Children national contact offices are located in countries in multiple continents and regions of the globe, including: Australia, Brazil, Canada, Denmark, Dominican Republic, Fiji, Finland, Germany, Guatemala, Honduras, Hong Kong, Iceland, India, Italy, Japan, Jordan, Korea, Lithuania, Mexico, the Netherlands, New Zealand, Norway, Romania, South Africa, Spain, Swaziland, Sweden, Switzerland, the United Kingdom, and the United States. Save the Children International works to save children's lives, fight for their rights, and help children fulfill their life potential (https://www.savethechildren.net/). The explicit mission of Save the Children International is "to inspire breakthroughs in the way the world treats children and to achieve immediate and lasting change in their lives" (Save the Children Annual Review, 2014: p. 1). The Save the Children organization works in approximately 120 countries around the world to provide humanitarian and social services support to children and their families who are affected by humanitarian emergencies caused by catastrophic events such as natural disasters, disease outbreaks, and armed conflict. The Save the Children organization helps children and their families recover from these humanitarian emergencies and rebuild their lives. In 2014, for example, Save the Children directly reached 4.3 million children around the world affected by conflicts, disease outbreaks, floods, and cyclones through 103 humanitarian responses, such as the Save the Children emergency disaster response to children and families impacted by Typhoon Haiyan in late 2013 and early 2014 (Save the Children Annual Review, 2014: pp. 4-5). In addition to emergency humanitarian assistance, Save the Children provides a full range of social services to children and their families, including: humanitarian assistance (basic needs such as shelter, protection, and clean water); life-saving medical treatment (for illnesses such as pneumonia and malaria); health and nutrition (including providing skilled birth attendants to mothers and babies, and health care to children suffering from malnutrition); education programming (in reading and literacy education); child protection (protecting children from harmful work and separation from family members); and child rights governance and advocacy (working with human rights organizations and governments to ensure a robust commitment and greater public investment of resources to support children's rights). Save the Children International maintains global partnerships with multiple corporate and venture partners committed to saving the lives and supporting the learning and social development needs of the world's children.

The above three network organizations can serve as exemplars of the kinds of innovative programs and collaborative partnership designs - operating with a regional and/or global reach — that are presently having a positive impact in addressing the turnaround leadership challenges associated with providing needed social services and educational opportunities to disadvantaged and marginalized children and youth. A distinguishing common feature of these network organizations is that they all leverage the power of collaborative partnerships as a means to effect positive social change. Through nurturing community, regional, and global partnerships with multiple governmental agencies, business professionals and corporate sponsors, and community volunteers, these organizations are able to leverage a multi-entity network teaming approach to creatively serve the learning and development needs of large numbers of disadvantaged children and youth.

\section{$2.2 \quad$ School Turnaround Leadership Challenges in STEM Inquiry and Instructional Technology Integration}

Ongoing technological advances in many scientific fields (e.g., astronomy, biomedicine and nanotechnology, physics, computer science, economics) and industries (e.g., agribusiness, infrastructure development, health care, renewable energy, space exploration), coupled with the expanding resource production and sustainability needs of a burgeoning world population, are fueling a growing demand to prepare upcoming generations of young people in both developed and developing countries around the world to be able to enter the global scientific and industrial workforce. These new global workforce 
demands require that present and upcoming generations of the world's young people have access to high-quality, twenty-first-century career learning opportunities through involvement in STEM (i.e., science, technology, engineering, and mathematics) education programs. To ensure that young people are provided at an early age with a solid grounding in science and mathematics, STEM education programs need to be integral components of comprehensive "pre-school to young adult" (P-20) school curricula. These STEM education programs should be designed to provide students with a diversified array of basic science and math developmental learning opportunities and experiences extending from early elementary level (pre-kindergarten and early childhood education) to secondary level (middle and high school) and continuing on seamlessly through college or university training. Additionally, as a result of the global communications revolution - a phenomenon spurred on by ever-accelerating advances in digital computer technologies and the internet (worldwide web) impacting and transforming both the nature and scale of scientific inquiry and industrial operations and the ways people work and collaborate together around the world (Bonk, 2009) - STEM education programs must also leverage available twenty-first-century digital instructional technologies to fully support and expand students' learning experiences. These instructional technologies can potentially include an array of "classroom-based" technologies (computer labs, classroom data projectors, smart boards, etc.) as well as available "mobile learning" digital technologies (computer laptops, tablets, personal cell phones, and the like) and multiple social media communication tools (e.g., email, instant messaging, Youtube, Facebook, Twitter, LinkedIn, MySpace, Pinterest, Second Life, and similar internet-enabled collaborative sharing and networking tools). These kinds of digital communication and information sharing tools will certainly continue to play an increasingly important role both in global commerce and industry and in the world of education. The expanding role and impact of these digital tools will be driven in large part by web-based developers who will continue to explore possibilities for expanding and optimizing online communications networks and creating ever new and more diverse social media networking outlets. The instructional application potential of digital technologies and social media as integrated means to contribute to and be part of a concerted effort to continue to address the complex challenges of twentyfirst-century global education certainly seems to remain promising.

Technology-integrated learning in a variety of forms has been evolving steadily since the early 1990s in many countries around the world. Currently, there are multiple national and state initiatives operating in various countries that focus specifically on leveraging the learning potential of computer technologies to digitize education content and to transform schooling (Global Education Leaders' Program, 2013). For example, South Korea has initiated "SMART school" pilot programs that are designed to substantively expand the flexibility and efficiency potential of teaching and learning processes. Additionally, a number of other countries - including Brazil, Mexico, Russia, and Turkeyhave begun large-scale projects to digitize textbooks as a means to vastly expand learning opportunities for students. Both Australia and New Zealand have developed national platforms designed to support the use of online education content. In countries with large economies such as the United States and China, increasingly large numbers of students are learning in partly online or "hybrid instruction" schools (that is, schools that combine in-person and online instruction). In the US, for example, California has more elementary and secondary school districts and charter schools recognized for incorporating online and blended (hybrid instruction) learning than any other state. Fully online charter and district schools in California served approximately 40,000 students during the 2013-14 school year. Additionally, the number of students participating in blended (hybrid instruction) learning has increased 49 percent since 2013. As a result of this increase, California Learning Resource Network (CLRN) data sources indicate that the overall number of students involved in blended learning is perhaps as high as 250,000 (Evergreen Education Group, 2014: pp. 81-82). In other countries with smaller economies, such as Croatia, recent studies have generated evidence that the use of new media (personal computers, multimedia software, tablets, smart phones, social media networking) can decrease traditional differences between teachers and teaching practices in rural and urban areas, suggesting that students - when supported by digital technologies and the internet - can learn well even though they are situated in remote geographic areas (Topolovcan et al., 2013).

These ongoing developments in the global availability of technology-integrated learning opportunities have directly benefited the growth of STEM education programs. Indeed, many educators in the United States engaged in STEM education initiatives are increasingly employing problem-based learning (PBL) instructional techniques in connection with open-collaborative peer learning models of teaching to design 
and implement Global Science Education (GSE) learning projects as a means to expand their technology-integrated STEM teaching practices. These GSE initiatives reflect a growing recognition by school district leaders of the need to adequately prepare elementary and secondary students to become informed global citizens - that is, to develop both an informed awareness and a sense of communal responsibility toward addressing both the learning challenges and innovation opportunities associated with participation in a twenty-first-century global society. This "global learning" dimension of STEM education is strongly emphasized in the recent Next Generation Science Standards (NGSS) for teaching and learning science in American elementary and secondary schools being disseminated widely in the United States (National Academy of Sciences, 2012). The Next Generation Science Standards (NGSS) were developed through a joint collaborative effort in the United States of multiple professional educator and research organizations, including the National Research Council (NRC), the National Science Teachers Association (NSTA), and the American Association for the Advancement of Science (AAAS). The Next Generation Science Standards are based on a rigorous national Framework for K-12 Science Education (National Research Council, 2011) and focus specifically on STEM-integrated science teaching and learning in elementary and secondary classrooms. Notably, the NGSS standards place strong emphasis on the instructional value and importance of "breaking down classroom walls" and "expanding networked learning opportunities for students" through global, interconnected teaching and learning.

Indeed, educators can creatively leverage the NGSS standards' emphasis on global, interconnected teaching and learning as a starting point for designing a variety of global learning partnership initiatives that can substantively expand and deepen STEM inquiry and technology-integrated learning opportunities for students and teachers. In the next section, I describe a number of creative program initiatives that educators working in multiple countries around the world are engaging in as a means to: 1) establish long-term, global learning partnerships to advance technology-integrated STEM inquiry; and 2) provide new career learning opportunities to students to develop the next generations of STEMeducated citizens.

\section{Emerging Best Practices: Creating Opportunities for Regional and Global Collaboration in Promoting Technology-Integrated STEM Learning Integration}

Educators in elementary and secondary school settings in many countries and regions around the world are capitalizing on the leveraging power of collaborative partnering to design and implement multiple problem-based learning (PBL) projects to reenergize STEM learning for their students. These PBL projects often focus on a variety of real-world, twenty-first-century issues - such as: global environmental protection and sustainability, renewable energy development, biodiversity, health and medicine, etc. Importantly, educators are designing problem-based learning projects that are providing young people with hands-on learning experiences that can help prepare them for careers in twenty-firstcentury growth industries and fields.

In the United States, some of the most promising STEM education programs involve Global Science Education (GSE) learning partnership initiatives among educators and students in schools in multiple countries and continents. Within these kinds of GSE learning partnerships, educators are leveraging available internet-enabled communications and sharing technologies to design new instructional and collaborative research inquiry spaces for globally-connected learning and to create exciting collaborative teaching and peer learning opportunities for both students and colleagues. For example, secondary school administrative leaders in West Texas school districts in the southwestern United States are becoming increasingly interested in encouraging collaborative teams of teachers in their districts' middle/junior high and high schools to become involved in designing and implementing multiple global learning partnership projects with educators in other countries and continents as a means to spur students' interest in global STEM learning. Teachers in these West Texas school districts are working to identify partner schools in countries such as China and Australia to organize international teams of global STEM educators who have an interest in collaborating together as global instructional planning teams to design STEM problem-based learning projects on current STEM topics and issues of mutual interest. These problem-based learning projects can be creatively designed around topics of current, realworld interest to students, teachers, and regional business and industry professionals associated with the global partnering schools - topics such as biomedical engineering, water pollution, sustainable agriculture, etc. As an integral part of this global collaborative project design work, teachers in these global partner schools are able to work together in globally-connected instructional planning teams through utilizing 
readily available, internet-enabled communication and sharing technologies, such as email, QQ chat, instant messaging, LinkedIn, Twitter, Screencast (http://www.screencast-o-matic.com/), etc. These global teacher teams can brainstorm and develop specific interdisciplinary STEM learning projects for their students that are centered on problems of mutual research interest in both countries (such as: how to utilize limited water resources efficiently and creatively to optimize vegetable crop yields; or how to harness available natural wind and/or water energy to expand regional power resources). In these kinds of global STEM problem-based learning projects, students become engaged in investigating identified problems of mutual interest via immersion in communal e-learning networks with student peers in partner schools in different countries and continents and, in doing so, share learning perspectives and insights and build positive collaborative learning relationships. These global partnership projects, in many instances, also help educators to proactively address their own school district- and state-level "post-secondary readiness" performance accountability challenges in preparing students effectively for future college and university academic training. Most importantly, these global partnership programs leverage the availability of the internet and mobile computer technologies and social media to create new kinds of communal e-learning networks in global partner schools and school districts that can nurture positive, twenty-first-century open digital learning cultures for students, parents, teachers, school administrators, and school community members.

In addition to the above kinds of school district-initiated global partnering efforts, a variety of nonprofit corporations have emerged in recent years that seek to connect educators and business leaders in multiple countries around the world who are interested in engaging in global partnering to advance STEM learning for children and youth. For example, the Global STEM Education Center, Inc. (2014) (http://www.globalstemcenter.org/) is a nonprofit corporation based in Massachusetts in the United States that seeks "to bring together educators, K-20 students, and corporate partners to promote science, technology, engineering, and mathematics (STEM) educational initiatives that prepare students with the skills to succeed in diverse, international, team-based contexts" (Global STEM Education Center, 2014: "Welcome to Our Journey", retrieved at: http://www.globalstemcenter.org/welcome.html). Espousing core principles of educational skill readiness developed by the "Partnership for 21st Century Skills (P21)" US national education advocacy organization, the Global STEM Education Center seeks to be a catalyst in positioning "twenty-first-century readiness" as a central goal of kindergarten through twelfth grade (K-12) education in the US through nurturing global collaborative partnerships that connect multiple change agent leaders around the world working in education, business, communities, and governments. The "Partnership for 21st Century Skills (P21)" principles supported by the Global STEM Education Center revolve around six essential elements and action steps that include: 1) adopting global competency standards for students and teachers; 2) providing teachers with effective and scalable instructional support, resources, and tools; 3) instituting a new approach to language instruction that emphasizes world language learning through studying international and global economies, societies, and cultures; 4) developing "whole-school" models focused on international education (e.g., internationally-themed schools, transformation models for low-performing schools, virtual schools-within-a-school designs, regional dual language/immersion schools) involving business, foundation, and nonprofit partner support; 5) creating networks of districts, schools, and educators to drive implementation and innovation; and 6) providing global learning experiences for students and educators (through teacher exchanges, educational travel, virtual classroom interactions and exchanges, global academic competitions, etc.) (Partnership for 21st Century Skills State Framework on Global Education, retrieved at: http://www.p21.org/our-work/resources/for-educators/1493-state-frameworkon-global-ed). The Global STEM Education Center has already established global STEM partnerships between US schools and schools in France, the United Kingdom, Russia, Ukraine, Mexico, the Netherlands, and Norway, and is in the process of establishing additional partnerships with other schools in Mexico, New Zealand, Australia, China, Greenland, Iceland, Norway, and Sweden. These global education partnerships are continuing to create new, twenty-first-century STEM learning and skill development opportunities for students and teachers through focusing on bringing together educators, students, business leaders, and nonprofit partners from multiple countries and continents to design and engage in authentic collaborative learning experiences as a means to develop a well-prepared, twenty-first-century global workforce.

Finally, in addition to the above kinds of global partnership programs, the "global learning partnership" concept is also being leveraged effectively by higher education institutions in some 
developed countries to provide new collaborative learning opportunities to college-age students in developing countries. For example, in the European Union the Erasmus Mundus Project ELECTRA [Enhancing Learning in Eastern Neighboring Partner Institution (ENPI) Countries through Clean Technologies and Research-related Activities] was launched in 2012 as a means to provide learning partnership grants to university students and researchers to participate in collaborative visits to partner institutions. The specific focus of Project ELECTRA is "fostering collaboration between the European Union and their Eastern Neighboring countries to tackle environmental, energy, and sustainable development issues through research, education, and innovation" (ELECTRA Project, 2012). Students and researchers in European Union universities establish partner relationships with colleagues in Eastern Neighboring Partner Institutions (ENPI) to design collaborative research projects focused on addressing real-world environmental development and sustainability challenges of mutual interest. Extending through the 2013-2016 academic years, the ELECTRA Project awarded 248 grants to make collaborative study, research, and job opportunities available to citizens in the European Union and nationals from multiple Eastern Neighboring Partner Countries (i.e., Armenia, Azerbaijan, Belarusia, Georgia, and Ukraine). ELECTRA Project learning partnerships operating in the European Union and Eastern European region center on collaborative research initiatives in multiple study areas and practical research fields, including: environment information management systems, resource and waste management, renewable energy, land use management, and biodiversity (ELECTRA Project information retrievable at: http://www.electra-project.eu/). The Erasmus Mundus ELECTRA Project seeks to creatively tap into the collaborative learning and shared resource leveraging potential of global learning partnerships to generate environmental energy sustainable development strategies and practices in EU and ENPI countries. Project participants in this multinational collaborative endeavor center their environmental energy research efforts on national and transnational objectives that are anchored in a core set of real-world common actions, including: 1) developing and implementing clean technologies; 2) transitioning from today's energies to renewable energies; 3) utilizing sustainable "resource management plus energy efficiency" practices; and 4) creating healthy environments. Through providing multiple opportunities to EU and ENPI participants to conduct collaborative study within and across these four action areas, the ELECTRA Project equips university researchers in the European Union and Eastern European countries with a global learning partnership platform for delivering comprehensive, researchdriven education and training to college-age students to develop the new cadres of next-generation experts that will be needed for the emerging twenty-first-century environmental energy labor markets in these countries.

The above examples of global education partnerships share some important common characteristics. First, these global partnership programs provide multiple examples of ways in which educators are effectively leveraging available, internet-enabled communication and sharing tools to develop communal e-learning networks for students, teachers, and a variety of community and business partners. These elearning networks, in turn, are contributing to the development of open global digital learning cultures that can nurture the desire among participants (students, teachers, business, and governmental partners) to engage in long-term learning and research collaborations to harness STEM learning and resource applications to improve global society. Second, teachers' sustained involvement in collaborative team STEM problem-based learning project design planning, implementation, and evaluation efforts, in effect, is becoming a new form of immersive professional development for teachers. Teachers' own increasing competence through their work in these global partnership programs in learning how to tap the instructional integration potential of mobile digital technologies and social media to benefit their students, intriguingly, is also causing teachers to expand their own awareness of the potential of these twenty-first-century communication and sharing tools for reenergizing their own team-centered professional learning. Third, students and teachers participating in global partnership programs are afforded valuable opportunities to acquire new language and cultural fluency skills through interacting with their global learning partners, thus contributing to building their own expanded multicultural global literacy. Fourth, the ability to engage in adaptive, project-based "peer learning" is increasingly becoming a highly valued twenty-first-century job skill. These global partnership programs provide students involved with intensive peer learning experiences in STEM-related inquiry that can contribute in positive ways to their ongoing preparation for careers in STEM fields. Fifth, these kinds of global partnerships can sometimes become catalysts for business and industry leaders to make funding contributions to further support the continued development and expansion of these global learning 
programs. This is particularly the case in situations where business and industry leaders see clear benefits of these global partnership programs for helping to prepare young people for twenty-firstcentury job markets and business/industry careers. And, sixth, these global partnership programs are nurturing long-term global connections among students, educators, and multiple business/industry, community, and governmental partners situated in different countries and continents based on a strong, common bond - a desire to learn and improve the world through education.

\subsection{School Turnaround Leadership Challenges in Fostering Entrepreneurship Education}

In the second decade of the second millennium, nurturing the innovation talents and creative idea generation capabilities of young people is continuing be a critical area of focus for educators around the globe. Indeed, investing in the entrepreneurial thinking and skill development of today's youth is now, more than ever before, a pivotal component in working to build sustainable global economic development, create new jobs, and advance human prosperity. The term entrepreneurship, as defined by World Economic Forum analysts, is "a process that results in creativity, innovation, and growth. Innovative entrepreneurs come in all shapes and forms; its benefits are not limited to startups, innovative ventures, and new jobs. Entrepreneurship refers to an individual's ability to turn ideas into action and is therefore a key competence for all, helping young people to be more creative and selfconfident in whatever they undertake" (World Economic Forum, 2009: p. 9). In recent decades, the concept of entrepreneurialism has broadened even further beyond referring only to individuals who engage in creative business startups and who seek to maximize profits to encompass notions of social entrepreneurship (individuals who address and seek to apply entrepreneurial principles to social problems), intra-organizational entrepreneurship (individuals who seek to bring about innovative changes within individual organizations), and policy entrepreneurship (individuals who work to insert innovative, entrepreneurial-driven policy improvement ideas within public and governmental institutions) (Zhao, 2012: pp. 3-4). In the educational arena, well-designed entrepreneurship education programs can engage educators, students, and business community partners in multiple forms of interdisciplinary, inter-organizational, multi-cultural, and multi-generational work-work that can revitalize the social fabric of communities through creating new learning and career opportunities for young people and their entrepreneurial mentors.

Despite a clear recognition by governmental, economic, and social leaders of the need to provide entrepreneurial education opportunities to the world's citizens, many countries across the globe are still grappling with an array of economic development challenges. For example, countries such as Afghanistan, Chad, the Democratic Republic of Congo, Mali, Niger, Somalia, Uganda, and Zambia all have total fertility rates of more than 6.0 , which is three times higher than the population replacement level of 2.1 (World Bank Report, 2013: p. 122). The development challenges these countries are confronting are exacerbated by a variety of demographic factors, including high rates of population growth (projected to continue to increase in the coming decades) coupled with limited education access opportunities for substantial numbers of children and youth often spread over large geographic regions within each country. The population of Sub-Saharan Africa alone is expected to double in size to nearly three billion people and constitute almost 20 percent (2.4 billion people) of the total world population by 2050. Total populations of countries in Asia and the Asian-Pacific Rim are also projected to continue to have large population increases in upcoming decades as well, with overall Asian populations exceeding 5.2 billion people by 2050 (United Nations Report, 2015). According to the 2015 United Nations Report entitled World Population Prospects: The 2015 Revision, nine countries-India, Nigeria, Pakistan, the Democratic Republic of Congo, Ethiopia, Tanzania, the United States, Indonesia, and Uganda-are expected to account for half of the world's population growth between now and 2050. Also, by the year 2050 six countries - China, India, Indonesia, Nigeria, Pakistan, and the United States - are expected to have populations of more than 300 million each (United Nations Report, 2015). With these global population projections as a looming reality, the economics of global information access is a growing concern. Internet access in many countries (both developed and developing) across the globe is still very expensive, with richer people and people who speak English continuing to have a clear advantage in internet accessibility. The internet access divide in developing countries and cities is particularly striking, with an hour of internet access in a cybercafé costing a resident of a developing city potentially twice as much of his or her daily income as the cost of similar internet access for a resident of a developed city 
(World Bank Report, 2013: p. 149). Moreover, the growing impact of the internet on how information is accessed is also continuing to contribute to a broader information and opportunities access divide, as admission applications to educational institutions, job applications, and governmental social services (e.g., identification cards, driver license applications and renewals, voter registration) in many countries are increasingly accessible only online.

These considerable population growth and information access challenges, however, are also serving as heightened stimuli to motivate many innovative program design specialists working in multiple education-focused organizations around the world to develop creative entrepreneurship education programs to address the global learning and career development needs of the world's growing numbers of young people. In the section below I highlight a few of the education-business organizational partnerships that have emerged in recent years that are supporting the design and implementation of creative entrepreneurship education programs.

Emerging Best Practices: Creating Opportunities for Regional and Global Collaboration in Nurturing Education-Business Partnerships to Support Entrepreneurship Education

Developing direct connections between "classroom-based" core conceptual content learning and "realworld" (i.e., problem-centered) learning experiences has become a central emphasis of several innovative educational partnership organizations that are working to create new kinds of twenty-first-century learning opportunities for secondary school-age youth. For example, in the United States, the Metropolitan Regional Career and Technical Center (MET) in Rhode Island, cofounded by social entrepreneurs Dennis Littky and Elliot Washor, is a not-for-profit learning organization that seeks to provide intensive, real-world learning and skill-building experiences to high school students (Metropolitan Regional Career and Technical Center, 2014). The Metropolitan Regional Career and Technical Center is one of 52 Big Picture Learning schools that have been established in recent years across the United States, and that now serve approximately 9,000 students. Similar entrepreneurialbased Big Picture Learning school startup organizations have also emerged as well in other countries around the world, including Australia, Canada, and the Netherlands (Hannon et al., 2013). Operating with a broad base of multiple regional community partners, the Metropolitan Regional Career and Technical Center connects students with business entrepreneurs and industry professionals in a wide range of fields (such as: commercial retailing, architecture, engineering, social services, etc.) to provide students with project-based internship experiences in various work settings. These internship experiences provide high school-age students with powerful learning experiences that make applying core conceptual content directly to the real world of work a fundamental part of learning. As an integral part of learning in the MET program "students work with their advisors to create individual learning plans that blend student passions and interests with core conceptual content. Learning is structured around projects that bring in other aspects of the curriculum. Collaborative learning is central to the approach" (Hannon et al., 2013: p. 85). Again, the overriding goal of schools like the innovative Metropolitan Regional Career and Technical Center in Rhode Island is to provide students with a "big picture learning" focus that offers students unique opportunities to enhance their content learning in core STEM content areasscience, technology, engineering, and mathematics - as well as further develop their communication skills in English/language arts and social studies through contextualized "project-based learning experiences" connected to the real world of work. As such, Big Picture Learning schools have a number of distinguishing characteristics, including an emphasis on: 1) learning in the real world; 2) personalization; 3) authentic assessment; 4) school organization; 5) advisory structure; 6) school culture; 7) leadership; 8) parent/family engagement; 9) school/college partnership; and 10) professional development (Metropolitan Regional Career and Technical Center, 2014).

As an extension of these "big picture learning" programs seeking to connect core conceptual content with students' real-world, project-centered passions and interests, educators in secondary school settings can provide their students with more formalized real-world learning and career development opportunities through initiating a variety of school-to-work programs. These school-to-work programs can include innovative school-business partnership designs that offer "work-study entrepreneurial placements" for senior high school students who are interested in acquiring professional skill development experiences as part of their secondary education. In these kinds of job-embedded entrepreneurial placements, high school students - as an integral part of their secondary school learning program - spend multiple hours each week logging work hours in a job-embedded entrepreneurial 
placement setting. For example, at several school districts in the Hill Country region of central Texas in the United States, high school students participating in school-to-work programs available on their campuses obtain "work placements" in a variety of local and regional business settings [such as: retail outlets, restaurants, regional farming co-operative centers, agricultural industry suppliers, travel and tourism hospitality management (hotels/motels, bed and breakfast facilities, gift shops, etc.), community service enterprises (local libraries, senior living centers, chamber of commerce offices, cultural activities information centers), etc.]. These work placements enable these secondary students to spend multiple hours each school week at their assigned work placement setting gaining valuable on-thejob career experiences and acquiring multiple professional work skills under the tutelage of adult business mentors. At these work placement sites students are thrust into the everyday world of client services in their entrepreneurial setting, providing students with excellent job-embedded opportunities to develop and refine their service leadership and interactive communication skills.

There are, in fact, a variety of creative school-to-work program designs that secondary school leaders can select from and customize to meet the academic and career-integrated learning needs of their students in individual school contexts. In some high schools, for example, school administrators and educators are working together to design and implement digital technology skills development programs for students. In these kinds of technology skills development programs, students are provided hands-on opportunities to gain knowledge and develop skills in graphic design, website design/development, and video production and post-production through directly integrating students' academic content learning in English/language arts with thematic/project-based learning activities in selected twenty-first-century digital video production and graphic design professional career tracks (such as: film production and cinematic arts, web-based business design, online product marketing, and multimedia advertising). School leaders are investing proactively in these creative programs through redirecting existing school resources, seeking additional external funding support, and rearranging teachers' instructional planning schedules to enable both grade-level and cross-grade teacher teams to engage in extensive project-based learning program planning, along with developing detailed project implementation strategies and data collection mechanisms to monitor and assess students' project-based learning effectiveness. In some high school contexts, these project-based learning teacher teams are expanded to include multiple school counselors, literacy coaches, school district information technology personnel, and career outreach specialists from the region's business and industry sector (e.g., radio and television stations, graphic/web design studios, architecture firms, marketing agencies) as a means to expand and enrich the mentoring support students receive in their academic and career-integrated project-based learning activities.

In addition to acting as professional mentors to high school students in these kinds of school-to-work programs, business and industry leaders can also make valuable contributions to ongoing school improvement efforts in their region through serving as invited business community members of school budget planning committees. With their broad experiences and insights in goals envisioning and in mining, analyzing, and leveraging data as coordinated means to maximize organizational performance, regional business and industry leaders can: 1) assist school planning committees in engaging in student learning program prioritizing and planning efforts that are consistent with school vision and mission statements; and 2) encourage school committee members to arrive at budgetary decisions that are datainformed and results-driven. Moreover, business and industry leaders' active involvement as community member participants on school planning committees can nurture an evolving climate of positive schoolbusiness community engagement that can lead potentially to eventual business and industry funding support of perceived "real-world relevant" school learning improvement initiatives. Additionally, as more and more school communities explore opportunities to create global STEM learning partnerships with school communities in other countries and continents, school-business partnership building can take on an expanded global collaboration dimension as globally-situated industries choose to "act locally" to create new learning opportunities for school-age students through becoming involved with and supporting local school communities in their various regions of industrial operation.

\section{Discussion}

In this section I present a literature-informed discussion of the education and social development challenges confronting today's global children and youth (highlighted in the preceding sections). As an 
integral part of this literature-informed discussion I offer an appraisal of some identified promising program efforts currently underway by global organizations and education leaders to address these challenges through providing meaningful opportunities to young people to broaden and enhance their career- and life-long learning and development for long-term success in the twenty-first-century global workplace. In addition, I highlight and discuss a number of creative ideas educators around the world can consider adopting and/or adapting to nurture multi-national and multi-regional collaborative learning partnerships that can have the power to significantly expand and deepen real-world learning for today's youth.

\subsection{Globalization and the Transformative Power of Communication Technologies as Means to Expand Learning and Career Development Opportunities for Twenty-First- Century Youth}

The continuing expansion of social and economic globalization trends occurring in the first two decades of the twenty-first century present some formidable challenges to the world's education leaders. As rapidly developing countries such as India and China continue their social development and job training programs to educate their populations in twenty-first century careers (including careers in computer/software programming and high-tech industry) - and, importantly, as corporate industry leaders continually seek to position their manufacturing and high-tech services production activities around the globe in countries where they can hire the cheapest workers, education and government leaders in countries across the globe must work diligently to ensure that their own well-educated young people can remain competitive in obtaining twenty-first-century jobs that provide adequate compensation for their work. In addition, as progress toward ever-increasing social and economic globalization continues to move forward, the personnel workforces of businesses and corporations are necessarily becoming more and more multinational and global in character. This new "multinational/global dimension" associated with many businesses and corporations operating in the global market today requires that these businesses and corporations engage on a daily basis in new kinds of internal and external communications with their employees, customers, suppliers, government agencies, and other regulation entities - some of whom may speak different languages and who come from diverse cultures. Thus, business/corporate managers must ensure that their employees are well trained to be able to navigate effectively the increasingly complex landscape of linguistic and cultural differences their diverse global constituents represent. At a developmental level, education leaders working in education systems across the globe to prepare young people proactively for careers in the twenty-first-century global marketplace can certainly work intentionally in designing and integrating multiple world language and cultural awareness learning courses into their overall educational and career development programs. Doing so will go a long way towards assisting young people in acquiring the kind of "global competence-centered" knowledge and skills they will need to be able to compete successfully for jobs in the globalized workforce. Perhaps, most fundamentally, educators working today in education systems in countries throughout the world need to focus intentionally and proactively in nurturing a strong sense of global citizenship in young people. As Zhao (2009) emphasizes: "As citizens of the globe, [young people] need to be aware of the global nature of societal issues, to care about people in distant places, to understand the nature of global economic integration, to appreciate the interconnectedness and interdependence of peoples, to respect and protect cultural diversity, to fight for social justice for all, and to protect plane Earth — home for all human beings" (Zhao, 2009: p. 113).

Intriguingly, these social and economic developments on the world stage will require that education leaders and education policy makers "rethink" how they develop globally conscious education policies and design, develop, and implement their twenty-first-century education programs. As Fazal Rizvi and Bob Lingard (2010) point out in their analysis of the need to embrace a global perspective on education systems design and educational policy-making: "Recent developments in information and communications technology, especially the satellite technologies, have revolutionized the circulation of ideas and information. It is now possible to transfer a large amount of money across national boundaries with the click of a computer key, and hold a meeting of the representatives of a transnational corporation from every continent without ever having them leave their offices. These developments have transformed the nature of economic activity, changing the modes of production and consumption. . . . in 
the age of globalization, time and space have become compressed in a number of ways, through better communication, virtual contact, cheaper travel and digitization. Capitalism has clearly taken advantage of these possibilities, stretching the reach of markets and bringing the whole globe into its sphere of influence" (Rizvi \& Lingard, 2010: p. 26). As a result of this continually expanding "global economic perspective", Rizvi and Lingard argue that national systems of education and educational policies can no longer be determined solely by policy actors operating exclusively within an individual nation-state, but must be forged intentionally through navigating a wide range of complex processes that take place across transnational and globally networked spaces. Thus, education leaders and policy makers tasked with designing and implementing forward-looking education systems and programs in the twenty-first century must to a large extent rethink the ways education policies affecting young people are developed, implemented, and evaluated.

The advances made in global, internet-enabled communication technologies in the past thirty years have been startling in the ways in which these internet-driven technologies have opened up new, almost instantaneous multiple communication and interaction opportunities for diverse people living and working in different regions of the globe (Bonk, 2009). Notably, these internet-enabled communication technology advances were jumpstarted directly through the pioneering efforts of Tim Berners-Lee in 1989, who implemented the first successful communication between a Hypertext Transfer Protocol (HTTP) client and a computer server via the Internet (Berners-Lee et al., 2001) — which was the inaugural "web-based digital communication" demonstration event that ushered in the emergence of the global "World Wide Web" or "Web". Within the timeframe of three decades, the Web and web-based communication technologies have dramatically impacted the way people around the world access information and interact/communicate with each other and have transformed the world into a global interconnected and interdependent economy (Hendler et al., 2008; Pejic-Bach et al., 2015). As a result, today's internet-driven communication technologies open up a whole new universe of interactive teaching, leading, and learning possibilities for globally conscious educators and students. In particular, education leaders can significantly expand and deepen their global learning in STEM-related fields (i.e., Science, Technology, Engineering, and Mathematics) through leveraging the communicative power of internet-enabled communication technologies (such as through using web-based interactive tools such as LinkedIn, live video streaming, and social media and mobile digital learning devices such as laptops, ipads, cell phones, and the like) to design, develop, and implement school- and classroom-based "STEM collaborative learning partnerships" to connect teachers and students (in a variety of elementary, secondary, and college/university instructional settings) in one country or region of the globe with likeminded teachers and students in other countries or regions. These STEM collaborative learning partnerships can involve teachers and students in planning and engaging in a variety of "problem-based learning projects" that are designed around real-world problems that are timely and of interest to students. Moreover, students can collaborate together in compiling the results/findings of their problembased learning investigations in meaningful "learning product reports and presentations" to their fellow students, parents, and community members through utilizing simple, widely available digital presentation design tools (such as: iMovie, Prezi, Strip Designer, Slide Rocket, and the like).

For example, a group of teachers and students working in a high school in Phoenix in south-central Arizona in the southwestern United States could initiate a "STEM collaborative learning partnership" with secondary teachers and students in a sister high school in Perth in southwestern Australia. This collaborative learning partnership could have as its central instructional purpose designing and engaging in a STEM-centered and technology-integrated real-world "problem-based learning" instructional unit that would focus directly on investigating how local farmers and horticulturists operating in both regions of the globe might be able to utilize current crop diversification/rotation processes and land irrigation techniques suited to arid soil/climate conditions in similar ways to increase crop yields and overall productivity in their respective regional farming lands. Similarly, other groups of teachers and students in a secondary high school setting in Austin, Texas could conceivably "partner" with groups of likeminded teachers and students in Mumbai, India - all of whom may have active interests in robotics and robotic applications - to develop a "problem-based learning project" to explore innovative, applied engineering techniques to envision and design new prosthetic devices that could one day be useful in enabling persons with limited limb functionalities or other motor-related disabilities to perform meaningful job tasks. Additional groups of teachers and students situated in other diverse countries and regions of the world could also form STEM collaborative learning partnerships to conceivably work 
together to design and implement collaborative learning partnership-driven "problem-based learning projects" on a number of other STEM-learning challenges, including such learning projects as: designing botanical and agricultural vegetable gardens to provide new food sources for local communities; initiating pre-medicine clubs and competitive school robotics teams; organizing hands-on science clubs to examine the effects of climate change on soil erosion, weather patterns, and farming practices in multiple land areas around the world. This kind of collaborative partnership-driven "problem-based learning project" instructional model has several distinctive teaching/learning advantages, including: 1) engaging students in working directly to identify a challenging real-world problem or question; 2) immersing students in sustained "technology-integrated" collaborative inquiry; 3) providing students with an authentic learning experience; 4) empowering students to have voice and choice in their own learning; 5) providing students with multiple opportunities for critical reflection and revision of their learning; and 6) enabling students to produce a public product they can present and share with students, parents, and community members. The problem-based learning project model can also significantly expand and deepen teachers' instructional planning, progress monitoring, and assessment practices through focusing collaborative teacher teams directly on: 1) aligning teaching/learning standards; 2) managing classroom- and field-based learning activities; 3) building a learning culture centered on realworld learning "problems" or "projects"; 4) scaffolding and assessing student learning; and 5) and engaging students meaningfully in real-world problem-solving with a "coaching" pedagogical mindset (Larmer et al., 2015: p. 34, 46).

Perhaps most importantly, these and other kinds of STEM collaborative learning partnership-driven and technology-integrated "project-based learning" initiatives and programs connecting teachers and students in both developed and developing countries and regions - in addition to broadening and deepening students' global STEM learning - can also go a long way toward raising students' (and teachers') awareness of the importance of understanding the value of embracing linguistic and cultural diversity as a means to build bridges of cultural understanding between and among peoples who live and work in multiple, disparate countries and regions around the world. Importantly, these kinds of global collaborative learning partnerships, if designed and implemented by teachers and students in earnest and supported enthusiastically by education organization administrative leaders, have the potential to foster new levels of "global competence" in young people - a global competence that will certainly: 1) further expand and develop young people's multi-linguistic and multi-cultural knowledge and skill sets in substantive ways that will enhance their cultural sensitivity and nurture their own positive global worldview; and 2) help prepare young people for meaningful careers in the twenty-first-century global workforce.

\subsection{Education Leadership in Developing Twenty-First-Century Entrepreneurs}

Importantly, to be able to become fully integrated into and benefit from the world's twenty-first-century global economy, today's youth - including those youth living in various regions of the world who may be economically disadvantaged and/or marginalized - need more than ever before to be educated in ways that will enable them to think and act entrepreneurially. Thinking and acting entrepreneurially essentially means simply being able to think resourcefully, flexibly, creatively, and globally (Zhao, 2012). Importantly, individuals seeking to pursue career/employment opportunities in today's twenty-firstcentury globally interdependent and interconnected society can "think and act entrepreneurially" without necessarily needing to own their own business or have a "business start-up" mindset-or necessarily have to invent and/or transform entire new global enterprises [such as in the case of Douglas Engelbart (1925-2013), who pioneered new interactive computing techniques that ushered in the personal computing revolution in the 1980s and early 1990s; or Steve Jobs (1955-2011) who, following on Engelbart's creative computer interface contributions, inspired a whole new computing operating system as well as accelerated a global digital communications revolution through the user-friendly interactive systems and devices he championed]. Twenty-first-century young people desiring to gain entry into and develop careers in corporate and/or small-business enterprise sectors can indeed be positively benefited by nurturing their own entrepreneurial mindset. This kind of entrepreneurial mindset is one that simply seeks to capture common "core qualities" shared by many successful entrepreneurs and business innovators, namely: inspiration, creativity, direct action, courage, and fortitude (Martin \& Osberg, 2007: pp. 32-33). 
Teachers can cultivate the development of an entrepreneurial spirit and skills in their students (i.e., an entrepreneurial mindset) through designing and involving students in problem-based learning projects in which students are focused on generating "end products or services" of community or regional interest, and in which students are given a real voice in the design and execution of the learning project. In this kind of "entrepreneurial-centered, problem-based learning" instructional model, students might work, for example, to address an authentic, real-world "need area" identified by stakeholder members of their own local and/or regional community. These problem-based learning projects can focus on a wide variety of potential community-centered need areas, such as: community/public parks landscaping and beautification, residential lighting and safety, water conservation, etc. Through immersing themselves directly in entrepreneurial-centered, problem-based learning projects, students become involved in producing a product or service of high quality for community members/consumers while internalizing new real-world problem-solving knowledge and skills. Yong Zhao (2012) explains the learning advantages of the entrepreneurial instructional model as follows: "In the entrepreneurial model, the students are in more control of the project. They propose and initiate the project. They need to convince the teacher to approve the project and, if needed, convince their peers to become partners. And for that they need to create a business plan, complete with documentations and analyses of targeted audience and needs, a feasibility analysis, and marketing strategies. The teacher, in this model, serves as the 'venture capitalist', who helps decide if the project is needed and feasible; the consultant, who provides suggestions and resources on demand; the motivator, who encourages at times of disappointment; the focus group, which provides feedback and critique on prototypes; and the partner, who provides complementary expertise and skills. The teacher or other adults could bring opportunities, help identify needs, make corrections to potential customers, or make suggestions for potential projects because of the expertise and social capital-but ultimately, it is the students who should decide what products to make" (Zhao, 2012, p. 203). Thus, to be able to be successful in the entrepreneurial instructional model, students are indeed challenged directly by their teachers and project-connected community members/stakeholders to develop their entrepreneurial thinking skills within their selected real-world, problem-based learning project endeavors. This demands that students work collaboratively and intentionally with their peers and instructors/mentors to tap into and cultivate their own creativity, inventiveness, and commitment to taking action to design and complete a needed new product or service.

Writing about the challenges corporate and small business leaders face in the twenty-first century in achieving "meaningfulness" in their entrepreneurial pursuits, Christian Madsbjerg (2017) argues persuasively that corporate/business leaders can successfully navigate their organizational worlds through cultivating a sense of connoisseurship. This sense of connoisseurship empowers corporate/business leaders to develop their interpretive skills in reading the world around them in ways that open up for these corporate/business leaders new insightful windows into purposefully and deeply scrutinizing and "making sense" of relevant knowledge. This process of "sense-making", as Madsbjerg explains, involves entrepreneurs making a conscious commitment to engage intentionally with their business/organizational worlds in ways that enable them to discern "meaningful differences"- that is, differences that can affect the overall creative quality of their entrepreneurial work. As Madsbjerg states: ". . . [in finding ways] to successfully navigate worlds with interpretative skills, I would like to return the word to its French origins: the verb connaitre means 'to be acquainted with' or 'to know somebody/a place'. Mastery - connaissance - is a way of navigating through a body of knowledge. . . . As we add more experience to our sense-making, we discover more analytical categories. This is the process of becoming a connoisseur: it is a way of navigating through the world" (Madsbjerg, 2017: pp. 183-184). In Madsbjerg's way of thinking regarding the value of adopting a "sense-making" stance to the art and practice of corporate/business leadership (as well as, thinking more broadly, to the accumulation of knowledge and craft skills in general), successful leadership in any kind of career pursuit or endeavor - both in corporate/business entrepreneurship and in other kinds of value-added knowledge and skills development pursuits - involves adopting the stance of a connoisseur or a "master artisan", that is, someone who leaves staid rules behind and stretches out into her/his own experience of the world. According to Madsbjerg, when master artisans are doing a skillful thing in the world they lose themselves. The distinction between the master and the world disappears. Master artisans leave wellworn rules behind and stretch out into their own experience of the world in order to experience and absorb the world on their own terms and through the interpretive lens of their own "individual perspectives". Master artisans "take risks" to achieve a new ideal of perfection based on and grounded 
squarely in what the artisan is committed to, what the artisan has defined her- or himself in terms of, and based on the artisan's insights into and understanding of what constitutes "meaningful differences" in her/his life (Madsbjerg, 2017: pp. 197-198).

Young people today who are striving to develop their overall knowledge and skill bases in meaningful ways and who are desiring to build successful, productive "twenty-first-century careers" in the global workplace -along with education leaders who are working to design and deliver forward-looking education systems and instructional programs that are capable of preparing young people effectively to acquire these kinds of useful, real-world knowledge and workplace skills - can benefit in positive ways through heeding Madsbjerg's clarion call to nurturing a "sense-making approach" to knowledge and skills development. This practice of sense-making engages young people in working intentionally to develop a real-world "interpretive-based" approach to their knowledge/skills and career developmentan approach that is grounded squarely in a recognition of the multiple "value-added and insightful contributions" the cultivation of a connoisseurship and master-artisan stance can bring to understanding and prospering in the twenty-first-century globally interconnected and interdependent world around them.

\subsection{Expanding Opportunities for Global Collaboration in Education and Social Development}

The examples highlighted in this article of some existing innovative programs in various countries and regions providing needed education and social services to children and youth certainly represent positive steps forward in education leaders' collaborative efforts to meet the twenty-first-century learning and social development needs of the world's children and youth. However, with many millions of children in multiple areas of the globe still lacking easy access to quality educational and social services supportoften because these children are born into conditions of poverty, live in geographically remote areas, and may also be unfortunate victims of social discrimination and/or regional conflict - there is still much work that needs to be done to ensure that twenty-first-century children and youth in all countries and regions of the world have access to high-quality and equitable learning and social development opportunities. In this regard, the needs of twenty-first-century children and youth continue to present today's education leaders with an urgent global collaboration agenda. On the positive side, global efforts to expand education and social services access opportunities to underserved children are being benefitted by a growing convergence of "positive education values" around the world. With education widely perceived by people in all areas of the world as being a transformative tool for building a better life, parents are passionately committed to taking advantage of any and all opportunities available to ensure that their children have access to quality education.

This universal desire for education can continue to serve as a primary driver for spurring on new global collaborative efforts by education leaders to design and implement innovative programs to meet the learning needs of children and youth. These global collaborative efforts can certainly include designing and delivering creative in-service professional teacher training support and learning resources to teachers who are working in remote regions through utilizing internet-enabled social media and communication tools in combination with available web-based educational technologies and instructional applications. These teacher training and learning resources can be modeled along the lines of some of the excellent teacher professional development materials that are already currently available on the worldwide web. Examples of these web-based teacher professional development resources can certainly include the excellent web-based professional development support packages provided as part of the Annenberg Learner "Teacher Resources and Professional Development Across the Curriculum" online materials (http://www.learner.org/) and the useful teacher professional development tools and video resources provided on the Edudemic "connecting education and technology" teacher resource website (http://www.edudemic.com/). Educators and instructional technology design specialists can work together in multiple educational innovation teams (teams that are situated proximally as well as dispersed geographically across multiple countries and regions around the world) to leverage the power of multimedia design tools and emerging global e-learning networks on the worldwide web to design and deliver "just-in-time digital teacher training and instructional support" to teachers working in remote areas. This instructional support can include developing and providing teachers with customized, 
culturally-specific teaching lessons and instructional modules to help these teachers better serve the particular learning needs of disadvantaged children and youth in these remote regions.

As global societal access to the worldwide web continues to steadily increase - fueled in large part by the fact that more and more young people around the world are using smartphones, tablet computers, and other related mobile digital technologies as their primary means of social communication-the way people interact with each other and learn using mobile digital tools is dramatically altering the landscape of global education. Intriguingly, the proliferation of twenty-first-century mobile communication and learning technologies is now enabling innovative thinkers to readily harness the power of these digital tools to design and engage in ever more expansive regional and global collaboration initiatives to provide new education and social development opportunities to the world's young people. These global initiatives will continue to create multiple new STEM-integrated learning and entrepreneurship engagement opportunities for youth interested in obtaining the kinds of rich, realworld-relevant educational experiences they need to pursue careers in high-demand, twenty-first-century fields such as digital technology application, health care, education and social services, renewable energy development, and space exploration. Most importantly, the innovative programs created by these global partnerships will be able to leverage highly creative instructional program designs - such as "flipped instruction" using integrated video and multimedia on demand (Khan, 2012; Khan Academy, 2015: https://www.khanacademy.org/) and "open courseware" (e.g., MIT OpenCourseWare, 2015: http://ocw.mit.edu/index.htm; Open Education Consortium 2015: http://www.oeconsortium.org/) - to enable educators to distribute multi-leveled, culturally sensitive, and content-rich learning resources to young people in every region of the world.

\section{Practical Education Leadership Action Strategies to Expand Global Education and Social Development Opportunities for Children and Youth}

The above discussion suggests a number of practical education leadership action strategies educators working in a variety of education organizations can implement to expand global learning and social development opportunities for children and youth. Education leaders working in diverse countries and regions of the world can consider employing these strategies as intentional means to expand and deepen their ongoing educational mentoring and developmental support of children and youth in ways that help young people maximize their career prospects and life-long learning opportunities.

Education leaders around the world can consider utilizing a variety of practical action strategies, such as the ones listed below, to enhance positive learning and social development opportunities for twentyfirst-century children and youth. Some specific "practical action strategies" education leaders can employ to expand and enhance education and social development opportunities for children and youth in countries and regions around the world include the following:

Collaborate with multi-national organizations and entities to provide teachers around the world with creative, just-in-time professional development and training resources to enhance their instructional practices. Education leaders dispersed geographically in multiple countries and regions around the world (working in a variety of organizational settings, including schools and school districts, colleges and universities, regional research centers, education resource development companies, etc.) can leverage the power of internet-enabled communication technologies and social media tools to engage collaboratively to design, develop, and disseminate creative in-service professional teacher training support and professional learning programs and resources to provide up-to-date, just-in-time modular professional development and training resources to teachers working in elementary, secondary, and postsecondary teaching/learning environments around the world. These professional learning programs and resources can be creatively designed to enable teachers working in disparate parts of the world-including geographically isolated and economically challenged regions - to be able to adapt and customize these programs and resources in ways that are easily implementable in their own educational settings.

Design innovative education and small business/corporate organizational partnerships to develop education / work-study programs to provide real-world learning experiences and career opportunities for disadvantaged youth. Education leaders can work proactively to develop creative collaborative partnerships with small businesses, corporations, governments, social services and 
social welfare agencies, and community volunteer groups to design and provide a variety of innovative "education / work-study programs" for economically disadvantaged and marginalized youth. The continued success of such programs as the Cristo Rey Network "work-study program" (http://www.cristoreynetwork.org/) in the United States and the Pathways to Education (http://www.pathwaystoeducation.ca) community-based partnership program in Canada demonstrate the powerful impact these kinds of "work-study integrated" instructional programs can have in substantively expanding educational and career-development learning and advancement opportunities for economically disadvantaged and marginalized youth.

Provide organizational funding support for global STEM collaborative partnership initiatives and programs. Education leaders can work with a variety of organizations and entities in multiple countries and regions of the world (including local schools and school districts, institutions of higher learning, STEM-focused businesses and corporations, engineering firms, agricultural/farming cooperatives, digital media companies, community-based civic organizations, etc.) to connect students and teachers in multiple, diverse countries and regions of the world to engage in collaborative partnerships (using internet communication technologies and social media tools) to identify, develop, and implement meaningful, STEM-centered real-world applied learning projects. These kinds of STEM-centered applied learning projects (that can include real-world-relevant topics and challenging issues associated with a diverse array of twenty-first-century STEM-related fields, including agriculture, agronomy, architectural design, biomedical engineering, flood prevention, horticulture, nutrition, nursing and health care, robotics, social services, space exploration, telecommunications, etc.) empower educators and their students (who are situated in different countries and regions of the world and who have diverse linguistic and cultural backgrounds and heritages) to engage together - via the communicative power of the worldwide web and social media - in creative collaborative learning partnerships on educational topics and challenges of realworld relevance to their twenty-first-century lives.

Encourage young people to expand their "social capital" through developing in-person and online social networking relationships with multiple education mentors and business leaders. Young people today can leverage the power and widespread availability of internet-enabled digital communication technologies and social media tools to develop positive mentoring/networking relationships with multiple education mentors and business leaders (both in their immediate geographic localities and beyond) as a proactive means to build their own twenty-first-century social capital networks (Martinez \& McGrath, 2014: p. 184). Building these mentoring relationships through both "in-person and online social networking" can substantively expand young people's ongoing access to multiple kinds of information, advice, and assistance that education, business/community leaders, and others can provide across a variety of mentoring support topic areas. These support areas can certainly include (but are by no means limited to) providing current, relevant information, advice, and assistance to young people regarding such things as: 1) avenues for applying for and obtaining higher education scholarships; 2) entry-level job/career positions that are presently available in business companies and corporate firms in a variety of fields; and 3) long-term career advancement opportunities.

Guide young people in cultivating an entrepreneurial mindset. Education leaders currently practicing in schools and school districts, education programming development enterprises, and institutions of higher learning around the world can offer positive instructional and mentoring support to young people through designing, developing, and delivering educational preparation programs that assist students in cultivating an entrepreneurial mindset. Importantly, educators working directly with young people in diverse countries and regions of the world can proactively guide and mentor their students in positive, twenty-first-century "educationally-supportive ways" through assisting students in developing and refining their own innate faculties of inspiration, creativity, courage, fortitude, and the desire to take direct action in developing and proactively pursuing creative business startup ideas. These entrepreneurial attributeswidely recognized as foundational "core qualities" of successful business, organizational, and social entrepreneurs - can serve young people well as they strive to interact and engage successfully in our twenty-first-century interconnected and interdependent global economy.

Motivate young people to become "connoisseurs" in the ongoing practice of accumulating their own knowledge and occupational skill sets to give deep meaning to their lives and career endeavors. Education leaders can positively impact the intellectual and social development of 
young people through nurturing in their students a foundational "sense-making" stance toward the ongoing task of acquiring real-world knowledge and skills. This sense-making stance involves encouraging students to continually strive to stretch out into their own experience of the world (in the same way that master artisans do) in order to experience and absorb fully the world around them on their own terms and through the interpretive, critical lens of their own "individual perspectives". Through engaging in this kind of interpretive immersion in and internalization of the world through one's own individual perspective, young people can evolve in solid, positive ways into becoming true connoisseurs of their chosen craft or profession. In becoming true connoisseurs - that is, skilled in the art and practice of real-world "sense-making"-young people, perhaps most importantly, will learn how to confidently and effectively apply their accumulating knowledge and occupational skill sets to navigate and interact successfully in today's twenty-first-century, globally-interconnected world.

\section{Conclusion}

The three school turnaround leadership challenge areas identified and discussed in this article-i.e., serving the needs of economically disadvantaged and marginalized student populations; promoting STEM inquiry and instructional technology integration; and fostering entrepreneurship education-will certainly continue to be critical focus areas for education and social development leaders in the coming decades. In addition, the selected innovative education and social program initiatives highlighted in this article can certainly serve as positive evidence of creative advances being made by many education and social development leaders and their collaborative partners around the world in designing high-impact programs to meet the learning and social services support needs of twenty-first-century children and youth. Many of these programs are noteworthy in the various ways they combine content learning and career development opportunities to provide young people with integrated educational experiences to enhance their prospects for leading meaningful and productive lives. Finally, the practical education leadership action strategies articulated in this article are offered as creative ideas educators - working in a variety of education organizations around the world - can consider adapting and implementing in their own countries and geographic regions to expand global learning and social development opportunities for children and youth.

It will be incumbent on education leaders and social development organizations around the globe in the years ahead to continue to work proactively to allocate available funding to provide meaningful twenty-first-century education and social development opportunities for the world's children and youth through designing and implementing "high-impact" learning and social support programs - that is, programs that creatively leverage the power of regional and global collaborative partnerships and interactive social media tools to enhance learning and social development support for all. I am confident that the creative program designs and innovative partnering strategies reflected in the education and social support program initiatives briefly surveyed in this article will continue to inspire present and future education and social development leaders, researchers, and activists as they move forward proactively to work in collaborative ways to address these challenges. The incremental successes to date of these various creative program designs and implementation efforts certainly serve to direct our attention to the transformative power of collaborative partnering - both regionally and globally - as an effective organizational design strategy for developing and implementing comprehensive schooling and social services programs that can enhance twenty-first-century learning and career advancement opportunities for the world's children and youth.

Acknowledgments. An earlier version of this paper was presented as the General Chair Keynote Web Address by the author to the 2015 International Conference on Education and Social Development, Nanjing, Jiangsu, China.

\section{References}

1. Adelman, C. (2006). Answers in the Tool Box: Academic Intensity, Attendance patterns, and Bachelor's Degree Attainment. Washington, DC: Office of Educational Research and Improvement: U.S. Department of Education. 
2. Annenberg Learner (2015). Teacher Resources and Professional Development Across the Curriculum (1997-2015). Retrieved on March 24, 2019 from: http://www.learner.org/resources/browse.html

3. Arbona, C., \& Novy, D. M. (1990). Noncognitive dimensions as predictors of college success among Black, Mexican-American, and White students. Journal of College Student Development, 31, 415-422.

4. Berners-Lee, T., Hendler, J., \& Lassila, O. (2001). The Semantic Web. Scientific American, 284(5), 29-37.

5. Blase, J. (1998). The micropolitics of educational change. In International Handbook of Educational Change, A. Hargreaves, A. Lieberman, M. Fullan, and D. Hopkins (Eds.), pp. 544-557. Dordrecht, Netherlands: Kluwer Academic.

6. Bonk, C. J. (2009). The World is Open: How Web Technology is Revolutionizing Education. San Francisco, CA: Jossey-Bass.

7. Brown-Martin, G. (2014). Learning Reimagined: How the Connected Society is Transforming Learning. Doha, Qatar: Bloomsbury Qatar Foundation Publishing

8. Chang, M. J., Sharkness, J., Hurtado, S., \& Newman, C. B. (2014). What matters in college for retaining aspiring scientists and engineers from underrepresented racial groups. Journal of Research in Science Teaching, 51(5), 555-580.

9. Choy, S. P. (1999). College access and affordability. Education Statistics Quarterly, 1(2), 74-90.

10. Choy, S. P. (2004). Paying for college: Changes between 1990 and 2000 for full-time dependent undergraduates. In Conditions of Education 2004. Washington, DC: National Center for Education Statistics.

11. Cofer, J. (2000). A comparison of the influence of debtload on the persistence of students at public and private colleges. Journal of Student Financial Aid, 30(2), 30-58.

12. Cofer, J., \& Somers, P. (2000). Within-year persistence of students at two-year colleges. Community College Journal of Research and Practice, 24, 785-807.

13. Cole, D., \& Espinoza, A. (2008). Examining the academic success of Latino students in science, technology, engineering, and mathematics (STEM) majors. Journal of College Student Development, 49(4), 285-300.

14. College Board (2010). What It Costs to Go to College. New York: College Board.

15. Darling-Hammond, L. (2010). The Flat World and Education: How America's Commitment to Equity Will Determine Our Future. New York: Teachers College Press.

16. DesJardins, S. L., Ahlburg, D. A., \& McCall, B. P. (2002). A temporal investigation of factors related to timely degree completion. Journal of Higher Education, 73(5), 555-581.

17. Dowd, A. C., \& Coury, T. (2006). The effects of loans on persistence and attainment of community college students. Research in Higher Education, 47(1), 33-62.

18. Edudemic (2015). Teacher Guides to Technology and Learning. Retrieved on March 24, 2019 from: http://www.edudemic.com/guides/

19. ELECTRA Project (2012). Erasmus Mundus Project ELECTRA: Enhancing Learning in ENPI Countries through Clean Technologies and Research-related Activities. Retrieved on March 24, 2019 from: http://www.electra-project.eu/)

20. Evergreen Education Group (2014). Keeping Pace with K-12 Digital Learning 2014: An Annual Review of Policy and Practice (evergreenedgroup.com). Retrieved on March 24, 2019 from: http://www.kpk12.com/wpcontent/uploads/EEG_KP2014-fnl-lr.pdf

21. Gandara, P. (2006). Strengthening the academic pipeline leading to careers in math, science, and technology for Latino students. Journal of Hispanic Higher Education, 5(3), 222-237.

22. Gandara, P., \& Contreras, F. (2009). The Latino Education Crisis: The Consequences of Failed Social Policies. Cambridge, MA: Harvard University Press.

23. Global Education Leaders' Program (2013). Redesigning Education: Shaping Learning Systems Around the Globe. Seattle, WA: Booktrope.

24. Global STEM Education Center, Inc. (2014). Global STEM education partnering initiatives nonprofit corporation. Retrieved on March 24, 2019 from: http://www.globalstemcenter.org/

25. Hrabowski, F. A., \& Maton, K. I. (2009). Change institutional culture, and you change who goes into science. Academic, 95(3), 11-16.

26. Hannon, V., Gillinson, S., \& Shanks, L. (2013). Learning a Living: Radical Innovation in Education for Work. Doha, Qarar: Bloomsbury Qatar Foundation Publishing.

27. Heller, D. E. (2003). Informing Public Policy: Financial Aid and Student Persistence. Boulder, CO: Western Interstate Commission for Higher Education.

28. Hendler, J., Shadbolt, N., Hall, W., Berners-Lee, T., \& Weitzner, D. (2008). Web Science: An Interdisciplinary Approach to Understanding the Web. Communications of the ACM, 51(7), 60-69. 
29. Hess, A., (2017). Here's How Much It Costs To Go To College In The US Compared To Other Countries. (last checked 19 March 2019) Retrieved on March 24, 2019 from: https://www.cnbc.com/2017/07/13/heres-howmuch-it-costs-to-go-to-college-in-the-us-compared-to-other-countries.html

30. Khan, S. (2012). The One World Schoolhouse: Education Reimagined. London: Hodder \& Stoughton Ltd.

31. Khan Academy (2015). Khan Academy online learning website. Retrieved on March 24, 2019 from: https://www.khanacademy.org/

32. Larmer, J., Mergendoller, J., \& Boss, S. (2015). Setting the Standards for Project Based Learning: A Proven Approach to Rigorous Classroom Instruction. Alexandria, VA: Association for Supervision and Curriculum Development (ASCD).

33. Leadbeater, C. (2012). Innovations in Education: Lessons from Pioneers around the World. Doha, Qatar: Bloomsbury Qatar Foundation Publishing.

34. Leithwood, K., Harris, A., \& Strauss, T. (2010). Leading School Turnaround: How Successful Leaders Transform Low-Performing Schools. San Francisco, CA: Jossey-Bass.

35. Madsbjerg, C. (2017). Sensemaking: The Power of the Humanities in the Age of the Algorithm. New York: Hachette Books.

36. Martin, R. L., \& Osberg, S. (2007). Social entrepreneurship: The case for definition. Stanford Social Innovation Review 2007, 29-39.

37. Martinez, M. R., \& McGrath, D. (2014). Deeper Learning: How Eight Public Schools are Transforming Education in the Twenty-First Century. New York: The New Press.

38. Massachusetts Institute of Technology (2015). MIT OpenCourseWare. Retrieved on March 24, 2019 from: http://ocw.mit.edu/index.htm

39. McCowan, T., \& Unterhalter, E. (Eds.) (2015). Education and International Development: An Introduction. New York: Bloomsbury.

40. Metropolitan Regional Career and Technical Center (MET) (2014). Big Picture Learning. Retrieved on March 24, 2019 from: http://metcenter.org/

41. Minniti, M. (2011) (Ed). The Dynamics of Entrepreneurship: Evidence from the Global Entrepreneurship Monitor Data. New York: Oxford University Press.

42. Moore, J. L. (2006). A qualitative investigation of African American males' career trajectory in engineering: Implications for teachers, school counselors, and parents. Teachers College Record, 108(2), 246-266.

43. Moyn, S. (2018). Not enough: Human Rights in an Unequal World. Cambridge, MA: Harvard University Press.

44. Museus, S. D., (2010). Understanding racial differences in the effects of loans on degree attainment: A path analysis. Journal of College Student Retention: Research, Theory $\&$ Practice, 11(4), 499-527.

45. National Academy of Sciences (2012). Next Generation Science Standards: Executive Summary. Washington, D.C.: National Academies Press. Retrieved on March 24, 2019 from: http://www.nextgenscience.org/

46. National Research Council (2011). A Framework for K-12 Science Education: Practices, Cross-Cutting Concepts, and Core Ideas. Washington, D.C.: National Academies Press. Retrieved on March 24, 2019 from: http://www.nationalacademies.org/publications/index.html

47. Open Education Consortium (2015). The Global Network for Open Education. Retrieved on March 24, 2019 from: http://www.oeconsortium.org/

48. Pappano, L. (2010). Inside School Turnarounds: Urgent Hopes, Unfolding Stories. Cambridge, MA: Harvard Education Press.

49. Pathways to Education (2015). Pathways to Education Program Introduction and Overview. Retrieved on March 24, 2019 from:

50. http://www.pathwaystoeducation.ca/sites/default/files/pdf/Overview\%2021_10_10_0_revised.pdf

51. Pejic-Bach, M., Omazic, M. A., Zoroja, J., \& Vlahov, R. D. (2015). Barriers and Incentives for the Utilization of Web 3.0. In C. Wankel \& A. Stachowicz-Stanusch (Eds.), Emerging Web 3.0 / Semantic Web Applications in Higher Education: Growing Personalization and Wider Interconnections in Learning (pp. 13-37). Charlotte, NC: Information Age Publishing.

52. Reimers, F. (Ed.) (2000). Unequal Schools, Unequal Chances: The Challenges to Equal Opportunity in the Americas. Cambridge, MA: Harvard University Press.

53. Rizvi, F., \& Lingard, B. (2010). Globalizing Education Policy. New York: Routledge.

54. Sarason, S. (1990). The Predictable Failure of Educational Reform: Can We Change Course Before It's Too Late. San Francisco: Jossey-Bass.

55. Save the Children (2014). Save the Children Annual Review 2014. London, UK: Save the Children International. Retrieved on March 24, 2019 from: https://www.savethechildren.net/resources 
56. Szirmai, A., Naude, W., \& Goedhuys (2011). Entrepreneurship, Innovation, and Economic Development. New York: Oxford University Press.

57. Strayhorn, T. L. (2010). Undergraduate research participation and STEM graduate degree aspirations among students of color. In S. R. Harper and C. B. Newman (Eds.), Students of Color in STEM: Engineering a New Research Agenda. New Directions for Institutional Research (No. 148, 85-93). San Francisco: Jossey-Bass.

58. Topolovcan, T., Toplak, T., \& Matijevic, M. (2013). Ownership and Use of New Media by Teachers in Rural and Urban Areas of Croatia. Paper presented at the $1^{\text {st }}$ International Conference on Research and Education: Challenges Toward the Future, 24-25 May 2013. Retrieved on March 24, 2019 from: http://files.eric.ed.gov/fulltext/ED545362.pdf

59. United Nations Report (2015). World Population Prospects: The 2015 Revision, Key Findings and Advance Tables. United Nations Department of Economic and Social Affairs/Population Division. New York: United Nations.

60. Walpole, M. (2007). Economically and Educationally Challenged Students in Higher Education: Access to Outcomes. ASHE Higher Education Report, 33(3). San Francisco, CA: Jossey-Bass.

61. World Bank Report (2013). Inclusion Matters: The Foundation for Shared Prosperity. New Frontiers of Social Policy Series. Washington, DC: International Bank for Reconstruction and Development / The World Bank

62. World Bank Report (2015). Ending Poverty and Sharing Prosperity. Global Monitoring Report 2014/2015. Washington, DC: International Bank for Reconstruction and Development / The World Bank.

63. World Bank Report (2018). Learning to Realize Education's Promise. World Development Report 2018. Washington, DC: International Bank for Reconstruction and Development / The World Bank.

64. World Economic Forum (2009). Educating the Next Wave of Entrepreneurs: Unlocking Entrepreneurial Capabilities to Meet the Global Challenges of the $21^{\text {st }}$ Century. Geneva, Switzerland.

65. Zhao, Y. (2009). Catching Up or Leading the Way: American Education in the Age of Globalization. Alexandria, VA: Association for Supervision and Curriculum Development (ASCD).

66. Zhao, Y. (2012). World Class Learners: Educating Creative and Entrepreneurial Students. Thousand Oaks, CA: Corwin Press. 